\title{
We Speak of You, Virginia Woolf
}

Some children found your body three weeks later, only a short way downstream, near Asheham.

It may have lodged, for a time, the police concluded, under the piers of the bridge at Southease-

slender fragile neck, paternal nose, restless angular shoulders, hooded bright eyes.

The stone was still in the pocket of your fur coat.

Where was the blame, after all?

You were cremated at Brighton.

Leonard played your Beethoven quartet that night, and buried your ashes beneath the elms at Rodmell.

Destroy all my papers, you said, in your last note to Leonard, but he did not, of course, could not. Nor was that your intent. What was it you wished us to know and not quite to know?

We have your diaries, your letters to everyone, memoirs of Leonard and Vanessa, and the gossip of all Bloomsbury, have your photographs at two and twenty and two years before the end, have studies, copious studies, and biographies, including Quentin's, 
in which you are fulsomely exposed, your privileged, conflicted family, your peculiar education, your traumatic losses to death, your chronic, disabling neurasthenia,

in which it is exquisitely disclosed how your genius found itself in atmospheres of the undermined, in ambiguities strangely like experience, you whose glasses were twisted, who could not button yourself nor do your hair, who from your thirteenth year knew you had been insane and might be again,

how your dissonant luminous fragments tunneled beneath those turning lives, ruthfully into their wounded spaces, you who, fraught with neuroses, did not read Freud, feared abandonment, mockery, ignominy, who of a morning wished to be thought a nice child, of an afternoon wished to be overpowering, and secretly maligned whoever might disadmire, you who may have slandered your father and mother, whose self-protections so evaded, so exaggerated, whose amorous mortifications invented such strategies for Vanessa and Vita, for Clive and Lytton and Roger,

how you sublimated it all, all to the written page,

how you have taken your place with Eliot and Joyce, your real things discovered beneath the show, your revelations almost intelligible. 